\title{
Research on an Analytical Framework for Urban Spatial Structural and Functional Optimisation: A Case Study of Beijing City, China
}

\author{
Wenting Zhang and Bo Li *
}

check for

updates

Citation: Zhang, W.; Li, B. Research on an Analytical Framework for Urban Spatial Structural and Functional Optimisation: A Case Study of Beijing City, China. Land 2021, 10, 86. https://doi.org/ 10.3390/land10010086

Received: 11 December 2020

Accepted: 14 January 2021

Published: 18 January 2021

Publisher's Note: MDPI stays neutral with regard to jurisdictional claims in published maps and institutional affiliations.

Copyright: (c) 2021 by the authors. Licensee MDPI, Basel, Switzerland. This article is an open access article distributed under the terms and conditions of the Creative Commons Attribution (CC BY) license (https:/ / creativecommons.org/licenses/by/ $4.0 /)$.
Faculty of Geographical Science, College of Resources Science \& Technology, Beijing Normal University, Beijing 100875, China; zhangwenting@mail.bnu.edu.cn

* Correspondence: libo@bnu.edu.cn; Tel.: +86-1367-104-7495

\begin{abstract}
A number of severe ecological problems, and the altered structure of urban spaces, are ascribed to rapid urbanisation. Hence, an analytical framework for urban spatial structure and functional optimisation is highly beneficial to balance the contradiction between developing urban areas and protecting their ecosystems. In this paper, the proposed analytical framework included three parts. We first delineated the ecological suitability zones (ESZs) of Beijing City by applying the minimum cumulative resistance (MCR) model. Subsequently, considering various socioeconomic and natural environmental factors, the Markov chain model and future land-use simulation (FLUS) model were utilised to predict the urban spatial structure of Beijing in 2031. Finally, taking the ESZ results as a constraint, three scenarios were designed to optimise the extent of city sprawl: the business as usual (BAU) scenario, ecological security (ES) scenario and ecological priority (EP) scenario. We found that the ESZs contained three zones: an ecological control zone $(63 \%)$, a restricted development zone (22\%), and a concentrated development zone (15\%). After comparing the three scenarios, we discovered that the ES scenarios ensured the bottom line in terms of Beijing's ecological security. Additionally, under the EP scenario, the urban spatial structure and function were further optimised. Our study can provide new ideas and technical support for the reasonable layout of urban spatial structure.
\end{abstract}

Keywords: urban expansion; ecological suitability zones (ESZs); MCR model; FLUS model; analytical framework; Beijing

\section{Introduction}

Urban spatial structure refers to the spatial distribution of urban elements and the interaction and formation mechanism of these elements [1]. From the perspective of threedimensional space, urban spatial structure can be divided into horizontal and vertical structures [2,3]. Horizontal structure is usually characterised by the composition and spatial pattern of land-use types [4,5], while vertical structure is characterised by building and vegetation heights [6,7]. Urban function refers to the capability of urban space and its respective functional zoning [8]. In general, urban areas have production, living and ecological functions in any region [9-11]. Among these, the ecological function is foundational, providing support for human production and living. The coordinated development of urban spatial structure and function can promote sustainable urban development. Since 1978, China's urbanisation has profoundly influenced its urban spatial structure at an astonishing speed [12]. Under the background of ecological land occupation by development activities, ecological space is continually crowded out, and urban ecosystem service functions face severe tests and challenges. Moreover, China's urbanisation rate is continuously increasing, with predicted rates of $60 \%$ and $75 \%$ by 2020 and 2035, respectively [13]. Rapid urbanisation further aggravates the serious contradiction and conflict between the various functions of urban space. As a result, the impact of urbanisation has attracted a 
great deal of attention, which has proposed an imbalance in urban spatial structure and a decline in urban ecological functions, including reductions in carbon storage, biodiversity and cropland [14-17]. Therefore, against the new background of promoting ecological civil construction and building a beautiful China, exploring the collaborative optimisation of urban spatial structure and function is conducive to trading off the relationships between ecological protection and economic development, as well as construction and non-construction during rapid urbanisation. This has turned into an important topic concerning regional sustainable development. Through a literature review, we established a theoretical framework, as shown in Figure 1.

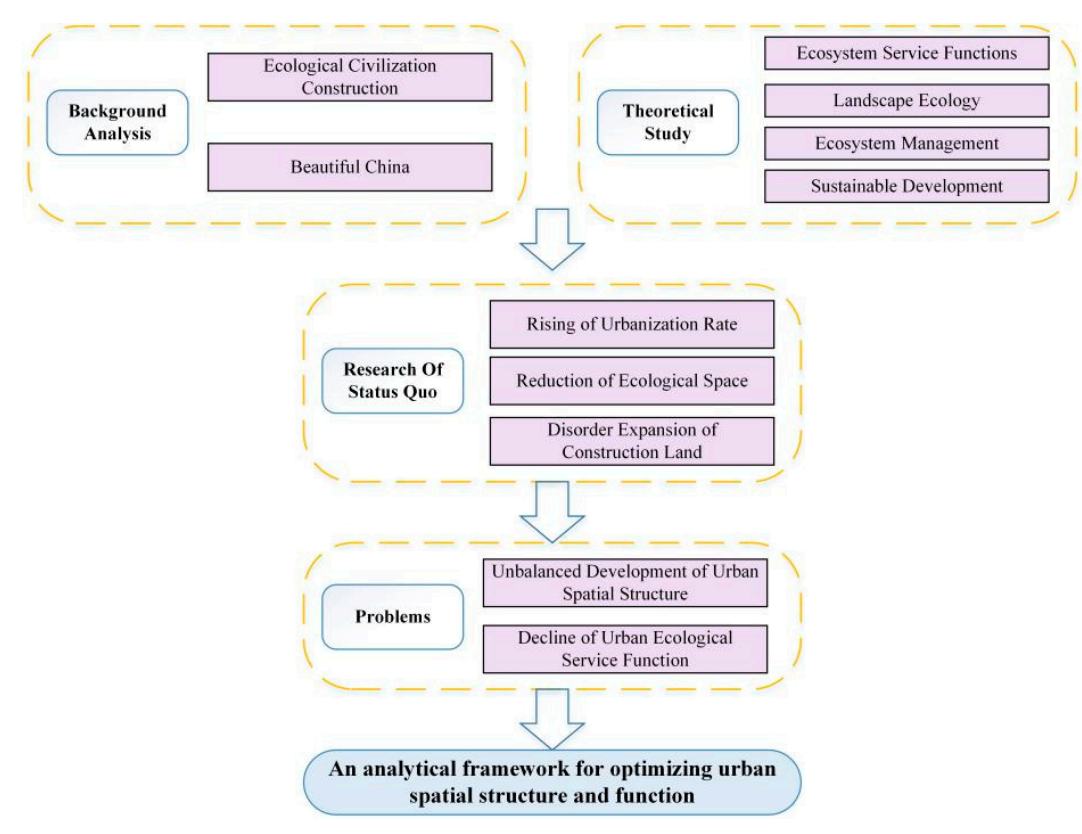

Figure 1. The theoretical framework.

Modelling methods have been widely used to optimise urban spatial structure; these methods include the system dynamic (SD) model [18], geomod model [19] and the cellular automata (CA) model [20]. Among various models, the CA model, because it can dynamically reflect the complex structure of an urban system, and its extended version models have been widely used in urban expansion simulation, such as the SLEUTH model [21], CLUE-S model [22,23], CLUMondo model [24,25], and the multiagent system (MAS) model $[26,27]$. However, most of the models simply set the conversion rules or train each land type separately to obtain the transfer probability. In the conversion process, each land type's relationship is ignored, making it difficult to discern the competition and mutual influence among all land types. The FLUS model, originating from the CA model, proposes the self-adaptive inertia competition mechanism. The probability of the occurrence of various landscape types and roulette selection is obtained through an artificial neural network (ANN) algorithm. As a result, the FLUS model can more effectively cope with urban sprawl's complexity and uncertainty under the joint influence of natural and anthropogenic activities [28]. Therefore, the FLUS model has provided novel research insight into urban expansion simulation, demarcating urban growth boundaries, resulting from its improved stimulation accuracy [29-31]. It is worth noting that, compared with human factors, the ecological and environmental constraints on urban expansion have relatively little influence. Hence, from the perspective of urban function, we used the MCR model to partition functional zones and to construct the ecological constraints to urban expansion, which, based on geographic information system (GIS) and landscape ecology theory (with fewer variables and simple operation), has been widely applied to evaluate urban space ecological suitability, delimit different urban function zones and construct ecological security patterns [32-34]. As far as we know, the previously reported 
optimisation of urban spatial structure and function has not put forward a complete analytical framework. According to landscape ecology theory, urban spatial structure and function are interdependent and interactive. In this paper, based on the new perspective of structure and function coupling, we choose the MCR model and FLUS model to construct an analytical framework for urban spatial structural and functional optimisation research.

As an international capital, Beijing's urbanisation in terms of its growth into a megacity with many functions has been remarkable. Over the past 40 years, it has encountered mismatches between urban spatial patterns and functions. As such, a series of effective measures have been promulgated to mitigate Beijing's problems, such as the relocation of noncapital functions, demarcation of urban ecological control lines, the definition of urban development boundaries, and demarcation of strategic blank land. All policies are aimed at optimising the city's spatial structure. Thus, we took Beijing as the study area for this research. The results will contribute to optimising spatial structure and enhancing urban ecological function. The findings will also be potentially useful for the integrated spatial structural optimisation of the Beijing-Tianjin-Hebei region.

\section{Materials and Methods}

\subsection{Study Area}

As the capital of China, Beijing $\left(39^{\circ} 26^{\prime}-41^{\circ} 03^{\prime} \mathrm{N}, 115^{\circ} 25^{\prime}-117^{\circ} 30^{\prime} \mathrm{E}\right)$ is located on the northwest edge of the North China Plain The total area is approximately $16,400 \mathrm{~km}^{2}$. Mountains surround Beijing on three sides, and the elevation of the region decreases from the northwest to the southeast, with altitudes ranging from $2258 \mathrm{~m}$ to $6 \mathrm{~m}$ (Figure 2). Beijing has a warm temperate continental monsoon climate, and its annual precipitation ranges from $600 \mathrm{~mm}$ to $700 \mathrm{~mm}$ on average. There are 16 municipal districts in Beijing. As of $2019,86.6 \%$ of Beijing's population is from urban areas, comprising approximately 18.65 million people.

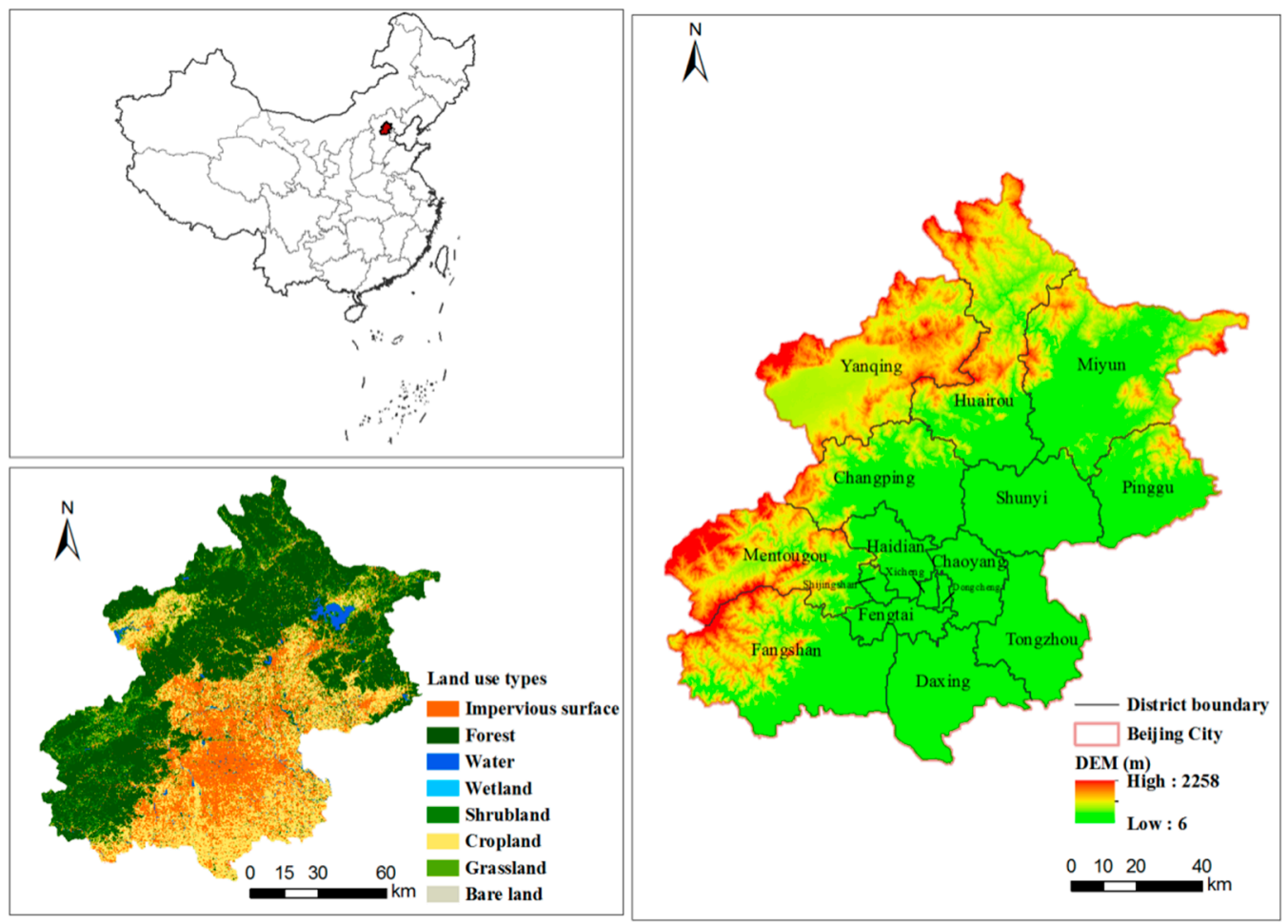

Figure 2. Location of Beijing.

\subsection{Data Sources}

Table A1 in Appendix A depicts the required natural and socioeconomic data for this study. Beijing's land-use data (2010-2017) were classified into: cropland, forest, grassland, 
shrubland, water, wetland, construction land and bare land. The same projection coordinate system (WGS_1984_UTM_Zone_50N) and spatial resolution $(30 \mathrm{~m} \times 30 \mathrm{~m})$ were utilised for all data and all grid data, respectively.

\subsection{Methods}

Based on the future urban spatial structure's simulation by the FLUS model, we innovatively proposed to optimize the urban spatial structure and function by combining the urban functional zoning, and taking the ecological control area, restricted construction area and concentrated construction area divided by the MCR model as the ecological conditions. The analytical framework for this paper is shown in Figure 3. There are three steps in total. The first step was to delimit the ESZs based on the MCR model. The second step was to combine the Markov chain model and FLUS model to imitate urban expansion without ecological constraints. The last step embedded the ESZs into the simulation result for future urban expansion optimisation simulation under three scenarios (Figure 3).

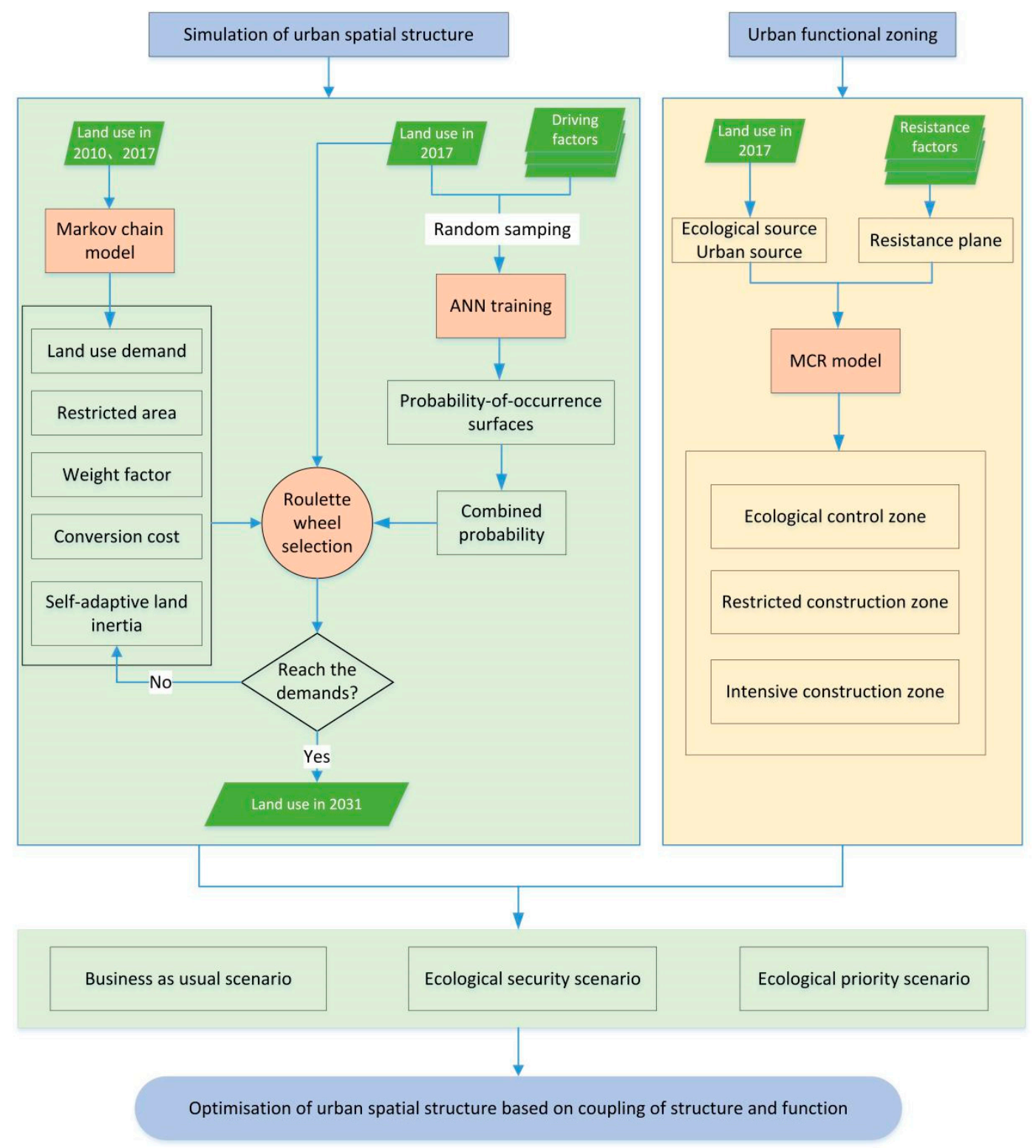

Figure 3. Framework of urban spatial structure and functional optimisation. 


\subsubsection{MCR Model}

\section{Model Variables}

\section{(1) Source selection}

Ecological sources i.e., landscape components promoting the development of processes in the landscape, play essential roles in the dispersal and maintenance of species [35]. Their three most important features are: providing key ecological service functions, maintaining continuity and integrity of landscape patterns, and preventing ecosystem degradation and subsequent ecological issues. Thus, land with an important ecosystem service function, or fragile ecological environments with high ecological sensitivity, will be called an 'ecological source'. In this paper, we defined forest, grassland, shrubland, water and wetland as ecological sources and construction land as an urban source.

(2) The construction of the resistance plane

Landscape emphasises spatial heterogeneity, which distinguishes different urban landscape units though different resistances. Urban landscape resistance refers to the cost or work performed to overcome the resistance from an ecological source through different landscapes, reflected by the resistance coefficient [36]. Combining the existing research results and data availability, our study selected seven elements to form a naturesociety composite resistance factor evaluation system, which included landscape types, normalized difference vegetation index (NDVI), digital elevation model (DEM), slope, ecological barrier, distance to road and urban areas. Based on the evaluation of ecosystem service function value by Costanza et al. [37], the resistance levels were divided into five, using the integers between 10 (lowest) and 100 (highest). The assignment of the urban source resistance coefficient created an inversion. The weight of the respective resistance factor was obtained through an analytic hierarchy process. The judgement matrix was then established, and the test coefficient of the matrix was 0.05 , which was less than 0.1 and passed consistency validation. The weight of each resistance factor was obtained. The resistance factor evaluation index system is listed in Table 1. Through weighed summation operations, we constructed the resistance plane of ecological and urban sources.

\section{Formula of the Model}

The MCR model was originally denoted as the cost of species moving from source to destination. It investigates urban ecological suitability by determining land connectivity, which simulates horizontal land ecological processes. It was first proposed by Knaapen [38]. We used the following formula modified by Yu [39]:

$$
M C R=f_{\min } \sum_{j=n}^{i=m} D_{i j} \times R_{i}
$$

where $M C R$ refers to the minimum cumulative resistance value; $D_{i j}$ is the spatial distance between source $i$ and source $j ; R_{i}$ denotes the resistance coefficient of grid $i$ to ecological sources; $f_{\min }$ represents the positive correlation function between the minimum cumulative resistance and the ecological process; and $n$ is the total number of landscape units. The cost-distance module in ArcGIS can be implemented by the model. 
Table 1. Evaluation factor system and resistance value of Beijing.

\begin{tabular}{|c|c|c|c|c|c|c|c|c|c|c|c|}
\hline \multicolumn{2}{|c|}{ Resistance Coefficient } & \multirow[b]{2}{*}{$\begin{array}{l}\text { Landscape } \\
\text { Type }\end{array}$} & \multirow{2}{*}{$\begin{array}{c}\text { Digital } \\
\text { Elevation } \\
\text { Model } \\
(\mathrm{DEM}) / \mathrm{m}\end{array}$} & \multirow[b]{2}{*}{ Slope $^{\circ}$} & \multirow{2}{*}{$\begin{array}{c}\text { Normalized } \\
\text { Difference } \\
\text { Vegetation } \\
\text { Index } \\
\text { (NDVI)/\% } \\
\end{array}$} & \multirow[b]{2}{*}{$\begin{array}{c}\text { Distance to } \\
\text { Urban/m }\end{array}$} & \multicolumn{4}{|c|}{ Distance to Road Network/m } & \multirow[b]{2}{*}{$\begin{array}{c}\text { Ecological } \\
\text { Barriers }\end{array}$} \\
\hline $\begin{array}{l}\text { Ecological } \\
\text { Source }\end{array}$ & $\begin{array}{l}\text { Urban } \\
\text { Source }\end{array}$ & & & & & & $\begin{array}{l}\text { Distance to } \\
\text { Express }\end{array}$ & $\begin{array}{c}\text { Distance to } \\
\text { Primary } \\
\text { Road }\end{array}$ & $\begin{array}{c}\text { Distance to } \\
\text { Second } \\
\text { Road }\end{array}$ & $\begin{array}{c}\text { Distance to } \\
\text { Tertiary } \\
\text { Road }\end{array}$ & \\
\hline 10 & 100 & Forest & $1760-2322$ & $>60$ & $>0.75$ & $>3000$ & $0-30,>4000$ & $0-30,>3000$ & $0-20,>3000$ & $0-15,>2000$ & $\begin{array}{c}\text { Ecological } \\
\text { protection } \\
\text { red line }\end{array}$ \\
\hline 30 & 70 & $\begin{array}{c}\text { Water/ } \\
\text { Wetland }\end{array}$ & $1290-1760$ & $45-60$ & $0.6-0.75$ & $2000-3000$ & $30-50,3000-4000$ & $2000-3000$ & $2000-3000$ & $1500-2000$ & $\begin{array}{c}\text { Basic } \\
\text { farmland }\end{array}$ \\
\hline 50 & 50 & $\begin{array}{l}\text { Grassland/ } \\
\text { Shrubland }\end{array}$ & $820-1290$ & $30-45$ & $0.45-0.6$ & $1000-2000$ & $2000-3000$ & $1500-2000$ & $1500-2000$ & $1000-1500$ & - \\
\hline 70 & 30 & $\begin{array}{l}\text { Cropland } \\
\text { Construction }\end{array}$ & $350-820$ & $15-30$ & $0.3-0.45$ & $500-1000$ & $1000-2000$ & $1000-1500$ & $1000-1500$ & $500-1000$ & - \\
\hline 100 & 10 & $\begin{array}{l}\text { land/ } \\
\text { Bare land }\end{array}$ & $-121-350$ & $<15$ & $<0.3$ & $<500$ & $50-1000$ & $30-1000$ & $20-1000$ & $15-500$ & Other areas \\
\hline \multicolumn{2}{|c|}{ Weight } & 0.2449 & 0.0447 & 0.0283 & 0.0192 & 0.0725 & \multicolumn{4}{|c|}{0.0996} & 0.4908 \\
\hline
\end{tabular}


Urban is a socio-economic-natural compound ecosystem. The land suitable for ecological protection has greater resistance to construction land, while the land suitable for construction has greater resistance to ecological land. Therefore, we choose ecological land and urban land as ecological sources and urban sources, respectively. The formula is as follows:

$$
M C R_{\text {diff }}=M C R_{\text {eco }}-M C R_{c s t r}
$$

where $M C R_{\text {eco }}$ and $M C R_{c s t r}$ refer to the minimum cumulative resistance of ecological sources and constructed sources, respectively. When $M C R_{\text {diff }}<0$, construction land expansion resistance is relatively large, hence the zone is suitable for ecological protection land. When $M C R_{\text {diff }}>0$, it greatly resists ecological protection land, and the expansion of construction land is suitable. When $M C R_{\text {diff }}=0$, the resistance for ecological protection and construction land expansion are equal, thus the zone is suitable for both; this can be regarded as the boundary. Accordingly, the natural break method of ArcGIS was employed to refine the zoning results into three categories: restricted construction zones, ecological control zones, and centralised construction zones.

\subsubsection{Markov Chain Model}

Premised on dynamic stochastic process theory, the Markov chain model assumes that the change of state at time $t+1$ is only related to time $t$ and that the transition probability matrix remains unchanged [40]. In addition, the model could predict land-use changes without continuous historical data. The formula is calculated as follows:

$$
X_{t+1}=X_{t} \times P
$$

where $X_{t}$ and $X_{t+1}$ denote the state at time $t$ and at time $t+1$, respectively, and $P$ refers to the transition probability matrix at time $t$.

In our study, Beijing's land-use demand in 2031 was obtained from the Markov chain model in two steps. The land-use data $(2010,2017)$ were first extracted, and the initial transition probability matrix was then obtained. Next, the land-use demand in 2031 (after two interval periods) was determined using the initial transition probability matrix, referring to 2017 as the initial year.

\subsubsection{FLUS Model}

The FLUS model consists of two main parts: the ANN-based probability of occurrence estimation and the self-adaptive inertia and competition mechanism CA. The ANN module comprises three layers: the input layer, the hidden layer and the output layer. The formula is calculated as follows:

$$
p(p, t, k)=\sum_{j} w_{j, k} \times \operatorname{sigmoid}\left(\operatorname{net}_{j}(p, t)\right)=\sum_{j} w_{j, k} \times\left[1+e^{-n e t_{j}(p, t)}\right]^{-1}
$$

where $p(p, t, k)$ represents the suitability probability of land-use type $k$ on grid $p$ and time $t$, $w_{j, k}$ represents the weight value between the hidden layer and the output layer, sigmoid () is the function between the hidden layer and the output layer, and $n e t_{j}(p, t)$ is the signal received on grid $p$ in hidden layer $j$ at time $t$.

The self-adaptive inertia and competition mechanism CA is the key part of the FLUS model. Based on the suitability probability distribution, it rationalises the spatial distribution of the total pixels of various land types in the future. The core is the adaptive inertia coefficient, determined by the difference between the existing land quantity and the land demand. The adaptive adjustment is carried out in the iterative process to make each land type's quantity develop towards the predetermined target. The formula is calculated as follows:

$$
T P_{p, k}^{t}=P_{p, k} \times \Omega_{p, k}^{t} \times \text { Inertial }_{k}^{t} \times\left(1-s c_{c \rightarrow k}\right)
$$




$$
\begin{aligned}
& \Omega_{p, k}^{t}=\frac{\sum_{N \times N} \operatorname{con}\left(c_{p}^{t-1}=k\right)}{N \times N-1} \times w_{k} \\
& \text { Inertial }_{k}^{t}= \begin{cases}\text { Inertial }_{k}^{t-1} & \text { if }\left|D_{k}^{t-1}\right| \leq\left|D_{k}^{t-2}\right| \\
\text { Inertial }_{k}^{t-1} \times \frac{D_{k}^{t-2}}{D_{k}^{t-1}} & \text { if } D_{k}^{t-1}<D_{k}^{t-2}<0 \\
\text { Inertial }_{k}^{t-1} \times \frac{D_{k}^{t-1}}{D_{k}^{t-2}} & \text { if } 0<D_{k}^{t-2}<D_{k}^{t-1}\end{cases}
\end{aligned}
$$

where $T P_{p, k}^{t}$ represents the total probability that grid $P$ is converted to land-use type $k$ at time $t, \Omega_{p, k}^{t}$ denotes the neighbourhood effect, $s c_{c \rightarrow k}$ is the conversion cost of landuse type $c$ to land-use type $k$, denotes in the $N \times N$ neighbourhood window (the total number of grids for the land-use type $k$ at the last iteration time $t-1), w_{k}$ is the weight of neighbourhood function of each land-use type, Inertial $l_{k}^{t}$ represents the adaptive inertia coefficient of land-use type $k$ at time $t$, and $D_{k}^{t-1}$ and $D_{k}^{t-2}$ are the differences between the number of grids and the demand of the land-use type $k$ at time $t-1$ and $t-2$, respectively,

In our study, we selected 14 driving factors (Figure 4) in the input layer, 12 neurons in the hidden layers and 8 land-use types in the output layer. To train the ANN module and obtain the suitability probability of 8 output layers, $1 \%$ of the total sample were randomly chosen. In the self-adaptive inertia competition mechanism module, we set the Moore neighbourhood at $3 \times 3$ for the simulation and the thread count at 8 in order to speed up [28]. In addition, we took advantage of the land-use conversion matrix to estimate the cost matrix. We estimated the neighbourhood weights accounting for the normalisation of the land expansion intensity index. Combined with neighbourhood weights, land-use demand, cost matrix, and the suitability probability of each land-use type, urban expansion could be evaluated by stimulating the rational allocation of the spatial distribution of each land type. This is essentially a process of making the output results constantly approach the target value through cyclic iteration.

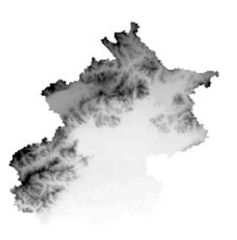

Annual mean temperature

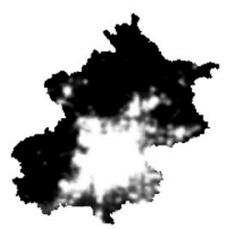

DMSP

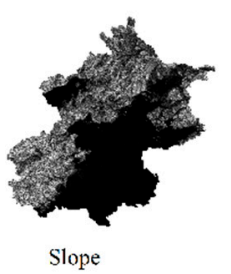

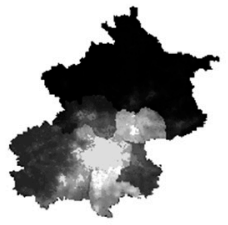

GDP

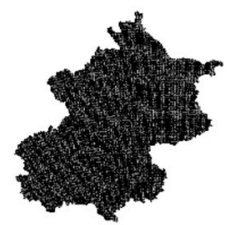

Aspect

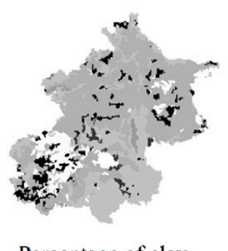

Figure 4. Driving factors of urban expansion.

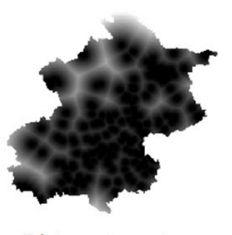

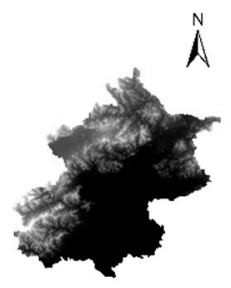

DEM

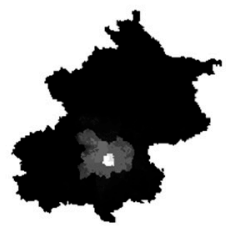

Population
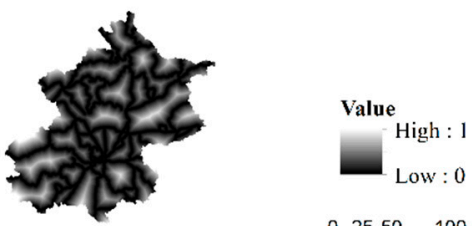

O $2550 \quad 100$

The figure of merit (FoM) [41] is used to evaluate the simulation accuracy in this paper, which precedes the common kappa coefficient [42-44]. 


\subsubsection{Design of Future Urban Expansion Scenarios}

This study proposed three urban expansion scenarios to maintain urban ecological security: the business as usual scenario (BAU), the ecological security scenario (ES), and the ecological priority scenario (EP). The specific design principles of each scenario were as follows:

(i) BAU scenario. This scenario was designed so that the historical rules of mutual transfer among each land type remain unchanged; the land-use demand in 2031 can be calculated on the basis of the initial transition probability matrix for the period of 2010-2017. All land-use types can be transformed from one to another without restrictions.

(ii) ES scenario. According to the ESZs, this scenario took the ecological control zone as the constraint condition and superimposed it on the BAU scenario result in 2031. Additionally, the construction land and cropland in the region are converted into forest, and the water and wetlands are kept stable, effectively guaranteeing ecological security.

(iii) EP scenarios. This scenario integrated the ecological control zone and restricted construction zone as the constraint conditions and superimposed them on the BAU scenario results in 2031. This scenario focuses on protecting ecological security within the ecological control zone; in addition, the new increase in construction land within the restricted construction zones should be controlled.

\section{Results}

\subsection{ESZs of Beijing}

\subsubsection{Comprehensive Resistance Planes of Beijing}

As shown in Figure 5, the two source expansion processes' comprehensive resistance plane results indicate that the two resistance surfaces' spatial patterns have opposite distributions. The resistance planes of ecological sources present a trend of west-low and east-high states (Figure 5A). In the western mountainous areas, the altitude is high, the slope is steep, the surface vegetation coverage is high, and human activities are few. While the resistance planes of urban sources generally present a higher trend in the west (Figure 5B), the plain area in the east is low in elevation and gentle in slope, with little resistance to urban expansion, and is conducive to urban land expansion. As shown in Figure $5 \mathrm{C}$, the region with a low difference in the minimum cumulative resistance is distributed in the western mountains in a north-south zonal distribution and is suitable for ecological land. The region with high difference in the minimum cumulative resistance is distributed in the eastern plain region, radiating outwards from downtown and is suitable for division into urban land.

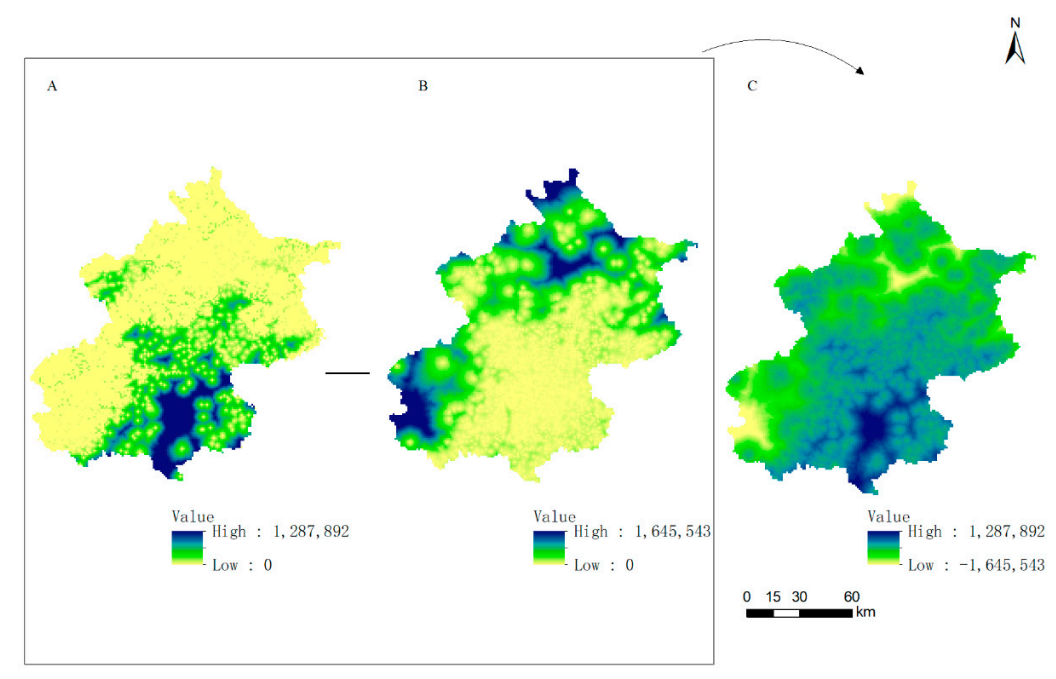

Figure 5. Minimal cumulative resistance surface of ecological sources (A) and urban sources (B) and the difference surface of Beijing city (A-C). 


\subsubsection{Distribution Characteristics of ESZs}

The results of the ESZs are shown in Figure 6, and the details of each zone are listed in Table 2.

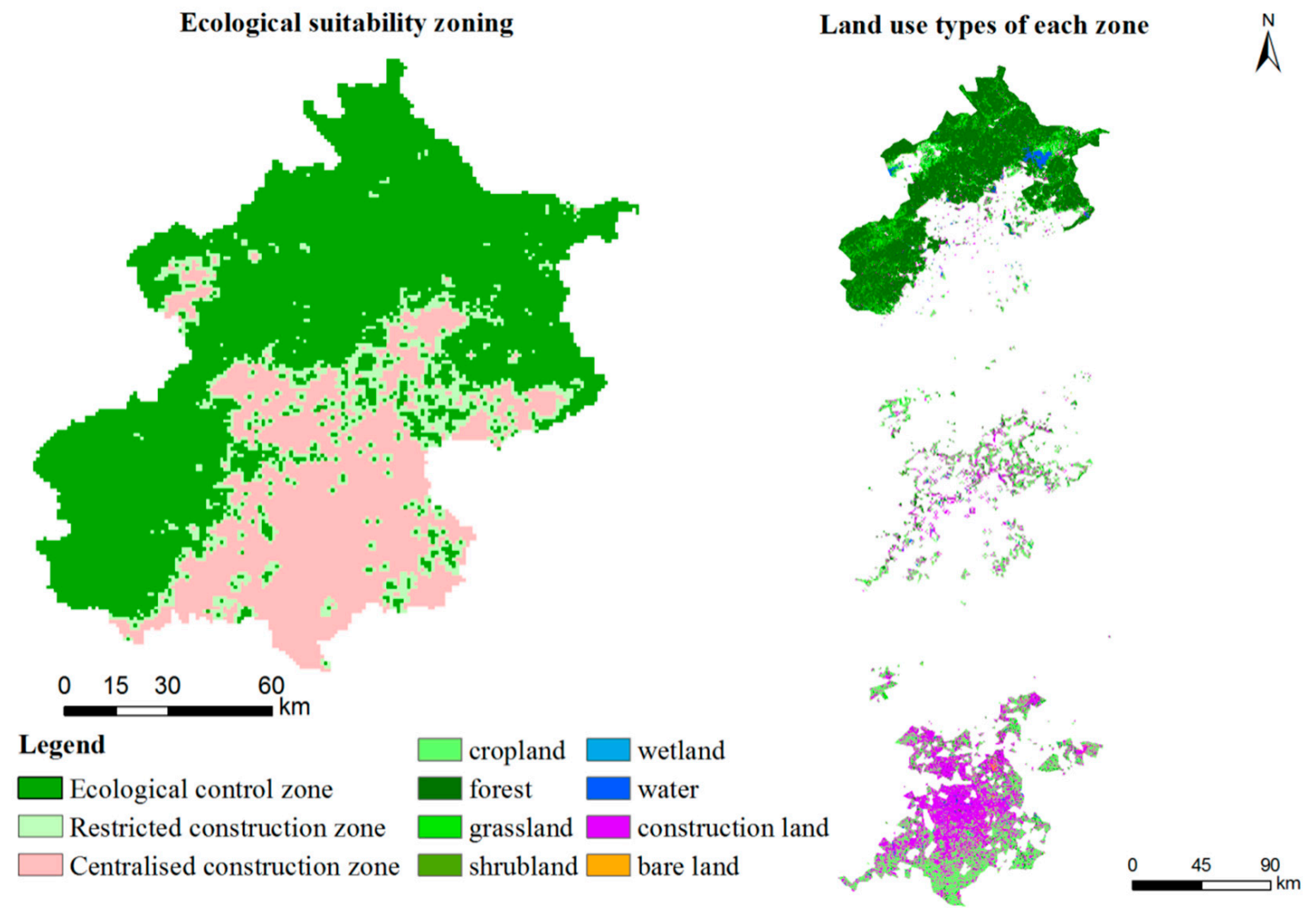

Figure 6. Ecological suitability zoning in Beijing.

Table 2. Ecological suitability zone of Beijing.

\begin{tabular}{|c|c|c|c|c|c|}
\hline \multirow{2}{*}{ Suitability Grade } & \multicolumn{2}{|c|}{ Expansion Difficulty } & \multirow[b]{2}{*}{ Threshold } & \multirow[b]{2}{*}{ Area $/ \mathrm{km}^{2}$} & \multirow[b]{2}{*}{ Proportion } \\
\hline & Ecological Land & Urban Land & & & \\
\hline Ecological Control Zone & Easy & Difficulty & $-1,319,737-0$ & 10,038 & $63 \%$ \\
\hline Restricted construction zone & Less easy & Less easy & $0-146,277$ & 3420 & $22 \%$ \\
\hline Centralised construction zone & Difficulty & Easy & $146,277-698,752$ & 2364 & $15 \%$ \\
\hline
\end{tabular}

The ecological control zone has the largest area at $10,038 \mathrm{~km}^{2}$, and it accounts for $63 \%$ of the city's total area. It is mainly surrounded by ecological sources and is distributed in the western mountainous area. The land type is mainly forest, and the scope is essentially the same as that of Beijing's ecological conservation area. The area covers many ecologically fragile areas, hence all urban construction activities in this area should be banned. The restricted construction zone's total area is $3420 \mathrm{~km}^{2}$, accounting for $22 \%$ of the city's area. It is scattered throughout the whole city, and the main land-use type is cropland. The ecological sensitivity of this region is relatively stable. Based on the concept of ecological priority, urban construction activities in this region should focus on ecological environmental governance and ecological restoration. Additionally, cropland should be protected by a strict and orderly development process. The centralised construction zone area accounts for $15 \%$ of the whole city area, at $2364 \mathrm{~km}^{2}$. The major land-use type is construction land. This area is far from forest, grassland and water and has weak ecosystem service functions. Therefore, it is the main urban area and suitable for the development of urban construction activities. 
3.2. Simulation of Urban Spatial Structure in Beijing from 2010 to 2017

\subsubsection{Verification of the FLUS Model}

The FLUS model has three accuracy verification models to evaluate its performance: the validation of the Markov chain model, the estimation of the ANN probability-ofoccurrence, and the validation between the simulation land-use pattern and the actual land-use pattern.

The Markov chain model was validated in our findings, in which the largest error $(-0.11 \%)$ was registered from forest. In contrast, all other landscape types exhibited a lower error rate than $0.02 \%$ (Table 3). These results indicate that the land-use change after the simulation is highly precise when the Markov chain model is utilised.

Table 3. Simulated and actual values of landscape types in 2017.

\begin{tabular}{ccccccccc}
\hline Landscape Types & Cropland & Forest & Shrub Land & Grassland & Water & Wetland & Construction Land & Bare Land \\
\hline Simulated values $\left(\mathrm{km}^{2}\right)$ & 4123 & 7613 & 278 & 1186 & 253 & 3 & 2870 & 55 \\
Actual values $\left(\mathrm{km}^{2}\right)$ & 4124 & 7621 & 278 & 1187 & 253 & 3 & 2871 & 55 \\
Error $(\%)$ & -0.02 & -0.11 & 0 & -0.08 & 0 & 0 & -0.03 & 0 \\
\hline
\end{tabular}

The RMSE of the ANN model performance was 0.259744 , indicating a high training accuracy. The ROC curve and AUC value were combined to quantify the accuracy of the individual land use type probability of occurrence [45]. Generally, an AUC value greater than 0.7 indicates a perfectly fitting result. Figure A1 shows that the AUC values of individual landscape types-cropland, forest, grassland, shrubland, water, wetland, construction land and bare land-were $0.83,0.88,0.79,0.77,0.87,0.93,0.86$, and 0.81 , respectively. Notably, all AUC values were larger than 0.75 , demonstrating the good explanatory ability of selected driving factors for each landscape type.

For the accuracy assessment result, the FoM has a relatively high value of $28.54 \%$, according to Pontius et al. [41], where most of the values are lower than $30 \%$.

\subsubsection{Simulation of Future Urban Expansion in Beijing in 2017}

The actual landscape patterns and the simulation results in 2017 are shown in Figure 7. In terms of spatial structure, a great deal of consistency was observed between the simulated spatial pattern and the actual spatial pattern in 2017. The construction land is mainly located in the southeast plain area, while it is scattered in the northwest mountainous area. Cropland exhibited a spatial pattern around construction land. The forest presents a north-south zonal distribution, which becomes Beijing's ecological barrier. Grassland and shrubland covered all counties. The water area is mainly distributed in the Guanting Reservoir and Miyun Reservoir. Wetland areas and bare land were less well distributed, most of which were found at certain points.

Compared with the actual values in 2017, forest expansion was evident, whereas other land changes were subtle.

\subsection{Optimisation of Urban Spatial Structure and Function in Beijing in 2031}

The simulation of the FLUS model is ascertained to be relatively accurate, according to the land-use simulation in 2017. Therefore, the FLUS model was adopted, with the same parameter setting, to identify different scenarios of land-use patterns in 2031 (Figure 8, Table 4). The land use structure comparison of Beijing in 2031 under the different scenarios is shown in Figure 9. 


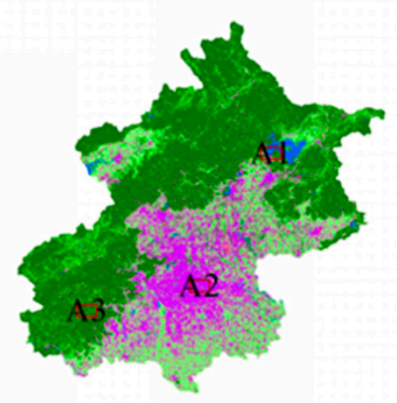

Actual land use pattern in 2017

$\AA^{N}$

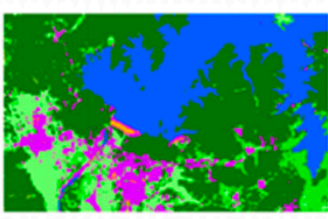

A1

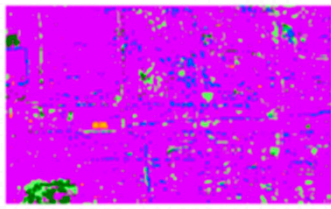

A2

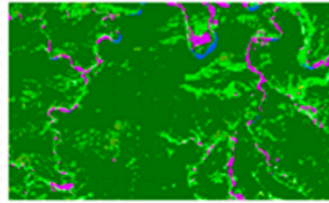

A3

Simulated land use pattern in 2017
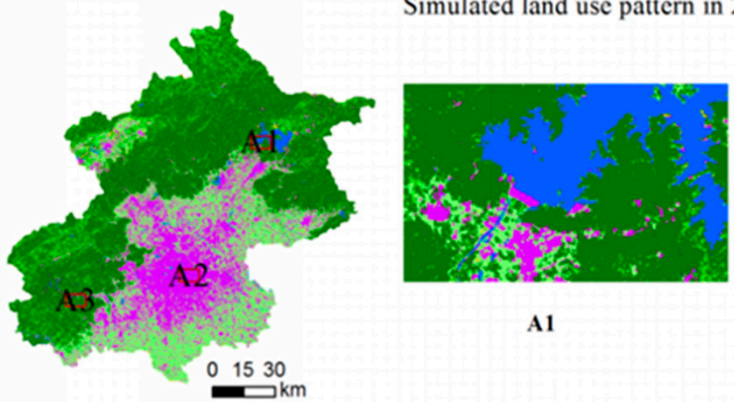

A

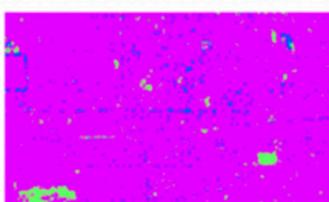

A2

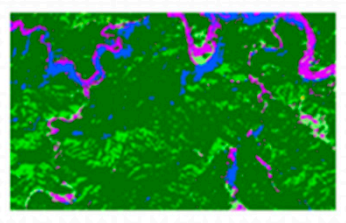

A3
Legend

$\square$ Cropland $\square$ Forest

Figure 7. Comparison of actual and simulated landscape patterns in Beijing for 2017.

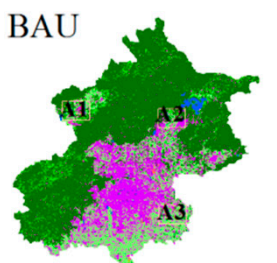

ES

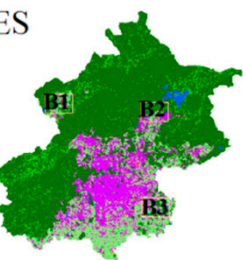

$\mathrm{EP}$

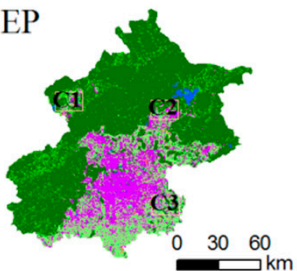

A1
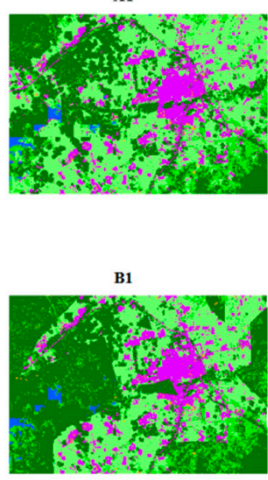

c1

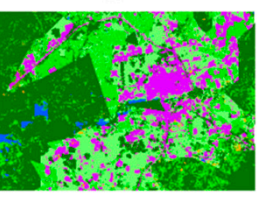

A2
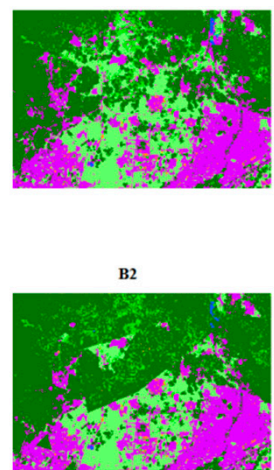

c2

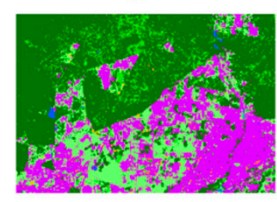

A3

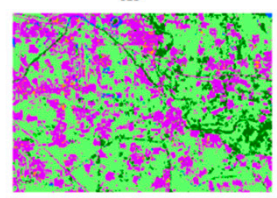

Legend

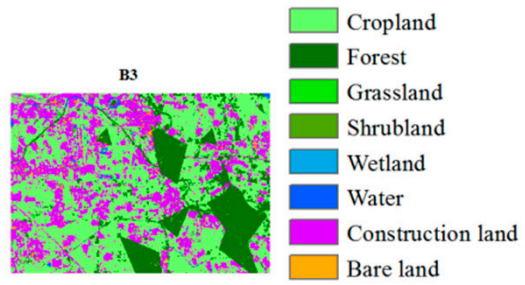

C3

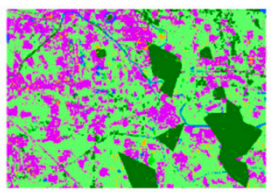

\begin{tabular}{lll}
0 & 2.5 & $5 \quad 10$ \\
\hline
\end{tabular}

Figure 8. The spatial patterns of land use in 2031 under different scenarios.

Table 4. The area of landscape types in 2031 under different scenarios $\left(\mathrm{km}^{2}\right)$.

\begin{tabular}{ccccccccc}
\hline LANDSCAPE TYPES & Cropland & Forest & Shrub Land & Grassland & Water & Wetland & Construction Land & Bare Land \\
\hline Business as usual (BAU) & 3020 & 9094 & 763 & 214 & 147 & 2 & 3112 & 41 \\
Ecological security (ES) & 2595 & 9803 & 763 & 214 & 147 & 2 & 2872 & 41 \\
Ecological priority (EP) & 2838 & 9581 & 767 & 215 & 169 & 2 & 2768 & 52 \\
\hline
\end{tabular}




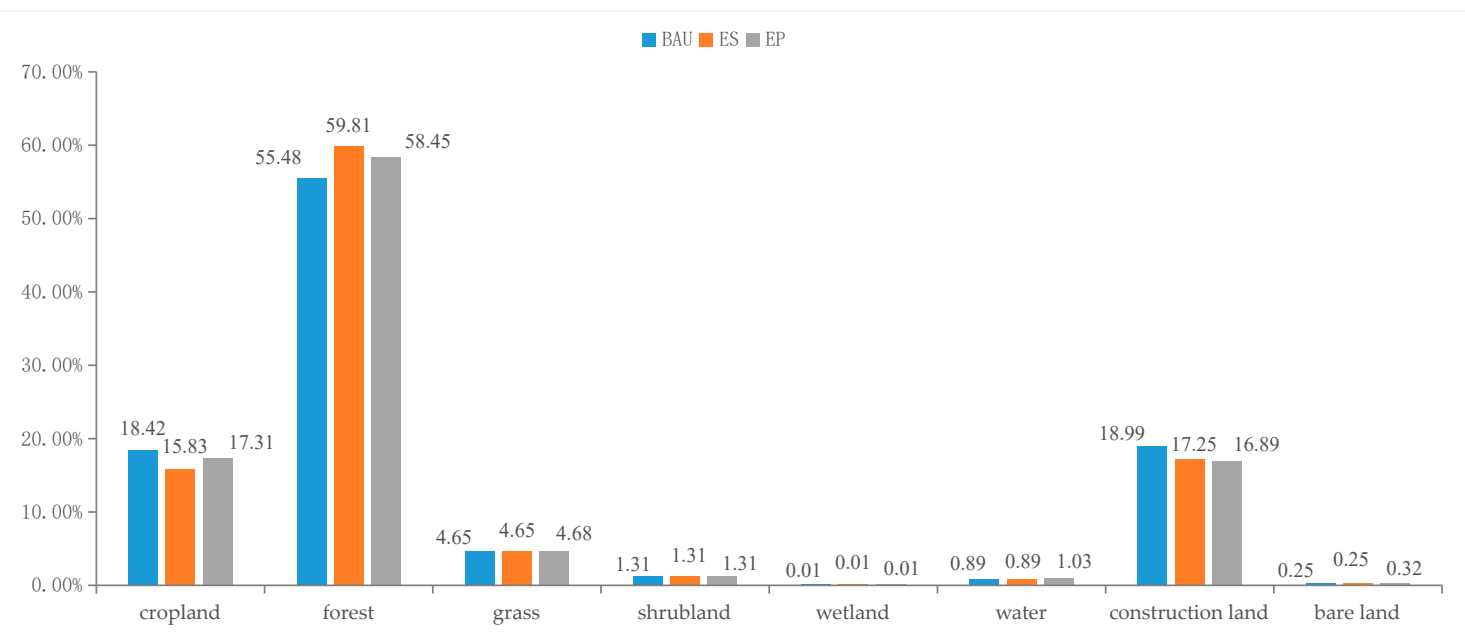

Figure 9. Land-use structure comparison of Beijing in 2031 under different scenarios.

Compared with the landscape pattern in 2017, cropland, grassland, water, wetland and bare land decreased under all three scenarios, while forest, shrubland and construction land areas (under the EP scenario) increased. Taking the land-use pattern under the three scenarios into consideration, the forest had the largest area of $9803 \mathrm{~km}^{2}$ under the ES scenario, accounting for $59.81 \%$; construction land had the minimum area of $2768 \mathrm{~km}^{2}$ under the EP scenario and the maximum area of $3112 \mathrm{~km}^{2}$ under the BAU scenario, accounting for $16.89 \%$ and $18.99 \%$, respectively. Compared with the ES scenario, the cropland area increased by $343 \mathrm{~km}^{2}$ under the EP scenario due to cropland conservation measures. Notably, the other land-use types exhibited stability within the three scenarios. Under the ES scenario and EP scenario, the ecological control zone had no construction land and cropland with productive functions in terms of spatial distribution. In contrast to the BAU scenario and ES scenario, under the EP scenario, the proportion of construction land decreased slightly with a more compact distribution, which prevented disorderly city expansion. In this way, the spatial structure of the city was further optimised.

\section{Discussion}

\subsection{The Analytical Framework of Urban Spatial Structural and Functional Optimisation}

This article proposed a comprehensive framework for urban spatial structural and functional optimisation by integrating the MCR model with the FLUS model. The analytical framework simulates urban space expansion under ecological constraints based on structure and function, preventing urban sprawl and maintaining urban ecological security. It is generally desirable that urban construction land frequently overlaps with the centralised construction area, while urban construction activities are far from the ecological control area. Nevertheless, the BAU scenario simulation results show that a large amount of ecological land will be occupied by construction land based on the current developmental trend. As a result, it is critical to benchmark the mitigation of the ecological pressure induced by urban expansion in the future. Based on this purpose, this paper divides urban ecological suitability by evaluating the ecological suitability of urban space. Additionally, the process of urban expansion is thoroughly evaluated and designed to realise the combination of construction land expansion and ecological land protection. The substance of this framework is to address the challenge of sustainable urban planning through anti-planning thinking, that is, to define the future urban spatial structure and functions under positive ecological constraints rather than making passive adjustments.

Compared with the research by Xiaoping Liu et al. [28], which only considers spatial structure without combining urban functional zoning, this paper improved on its performance. In addition, the establishment of the ESZs contains vertical and horizontal ecological processes. The vertical ecological process originates from the comprehensive 
analysis of seven resistance factors, while the horizontal ecological process is premised on the MCR model. This method allows for quantitative identification of ecologically controlled zones in multi-scenario urban expansion simulations rather than qualitative descriptions [46], representing objective and scientific research. In addition, in the study simulating urban growth under ecological constraints, Deng Yu et al. [47] pointed out that urban expansion should be combined with ecological function zoning to achieve the coordinated development of urban spatial structure and function, demonstrating the rationality of our paper's analytical framework.

\subsection{Differences between the Three Scenarios}

Urban expansion is a complex process of natural, economic and social coupling. Multi-scenario simulation can realise urban development direction under different policy guidance. Different urban development schemes are conducive to future urban expansion, and it is highly recommended to target land use according to existing land use. Our current work established three scenarios, namely, the BAU scenario, EP scenario and ES scenario. It then analysed the advantages and disadvantages of the optimal configuration of urban spatial structure and function under the different scenarios.

In the BAU scenario, the areas of cropland and construction land in 2031 were the largest. Construction land expanded significantly and far exceeds the planned area for 2035, encroaching substantially upon the forest because of the small change in shrubland, water, grassland and wetland areas. As shown in Figure 8, the degree of landscape fragmentation is relatively high. Therefore, the expanded scope of construction land in the future is extremely limited and the urban spatial structure seriously restricts the overall and coordinated development of Beijing.

In the ES scenario, the ecological control zone was well maintained and ecological security's bottom line was ensured. Moreover, the forest area in 2031 was the largest, while the cropland was the lowest under this scenario. This phenomenon is in line with the policy requirements of the Green Program in Beijing. The overall land-use pattern tended to be reasonable.

In the EP scenario, cropland was protected while preventing the disorderly expansion of construction land. The expansion of construction land has been effectively controlled, the cropland area has been increased, and the spatial structure of each land-use type has been optimised. Hence, the EP scenario can better balance the relationship between the developing economy and protecting the ecosystem than the BAU and ES scenarios.

Compared with Beijing's urban master plan (2016-2035), the area of construction land under the EP scenario is $2768 \mathrm{~km}^{2}$, which is in line with the master planning requirement to reduce the construction land area to $2760 \mathrm{~km}^{2}$ by 2035 . However, the proportion of ecological control area in the three scenarios is approximately $65 \%$, far lower than the $75 \%$ required by master planning. There may be two reasons for this. One is that the land-use data sources are different, thus, the classification and accuracy of land uses are different. The other is the different identification methods of ecological land, resulting in the difference in the proportion of ecological control areas. Our results are essentially consistent with the urban spatial structure's requirements and functions in Beijing's urban master plan (2016-2035), which could provide new ideas and technical support for the reasonable layout of urban spatial structure in a similar city.

\subsection{Limitations and Future Research Directions}

Urban expansion is a natural and socioeconomic process. The Markov-FLUS model assumes that transition rules such as the land-use transition probability matrix, transition cost and probability-of-occurrence estimation remain unchanged during the simulation process; however, this assumption does not always hold in practice, hence predicting future land-use patterns accurately remains a challenge, and more effort is needed to tackle this challenge in future work. Moreover, what calls for special attention is that the simulation results rely heavily on the original land-use data, thus, the data's precision is 
critical. In addition, although the proposed ESZs generated relatively ideal results, the value of the resistance coefficient used by the MCR model has been provided by scholars and is subjective to some extent. Therefore, it needs to be further modified.

\section{Conclusions}

Research on urban spatial structure and functional optimisation is a hot topic in academic circles. Taking Beijing as an example, an effective analytical framework is proposed to optimise urban spatial structures and functions by making development trade-offs between the urban economy and ecology. Rational zoning is dependent on ecological suitability evaluation using the MCR model. The Markov-FLUS model was proven effective in urban expansion research with a high FoM value upon comparing the simulated and actual landscape patterns in 2017. It is also worthy to note that construction land has the smallest area under the EP scenario because of the strict control of new construction land in the restricted construction zone, which is consistent with the "reduced development" strategy of construction land implemented in Beijing. Reduced development is the distinctive characteristic of high-quality development in the capital. Promoting reduced quantity and improved quality development for construction land can effectively protect the ecological environment, helping Beijing grow into a world-class, harmonious, and liveable capital, and conforms to the goal of Beijing's urban master planning (2016-2035). Hence, Beijing's spatial structure and function under the EP scenario mostly confirm the actual changes in future land use. In addition, the proposed analytical framework provides an effective solution for the exploration of urban spatial structure and functional optimisation, reducing construction land to make space for ecological land. This can be applied as a reference for urban planners.

Author Contributions: Conceptualisation, W.Z.; methodology, W.Z.; software, W.Z.; validation, W.Z.; formal analysis, B.L.; investigation, W.Z.; resources, W.Z.; data curation, W.Z.; writing-original draft preparation, W.Z.; writing — review and editing, B.L.; visualisation, W.Z.; supervision, B.L.; project administration, B.L.; funding acquisition, B.L. All authors have read and agreed to the published version of the manuscript.

Funding: This work is supported by the General Program of National Natural Science Foundation of China (Grant No. 42071228), and National Key Technology Support Program (Grant No.2014BAC15B04).

Acknowledgments: We wish to thank Qi Fu and Xun Liang for guidance on the FLUS model's problems.

Conflicts of Interest: We declare no conflict of interest.

\section{Appendix A}

Table A1. Details of data used in this study.

\begin{tabular}{|c|c|c|c|c|c|}
\hline Category & Data & Year & Data Type & Resolution & Data Resource \\
\hline Landscape & Land-use data & 2010-2017 & Raster & $30 \mathrm{~m}$ & $\begin{array}{c}\text { http: } \\
\text { //data.ess.tsinghua.edu.cn/ }\end{array}$ \\
\hline \multirow[t]{3}{*}{ Human influence } & Population & 2010 & Raster & $1 \mathrm{~km}$ & http://www.resdc.cn/ \\
\hline & $\begin{array}{l}\text { Gross Domestic } \\
\text { Product(GDP) }\end{array}$ & 2010 & Raster & $1 \mathrm{~km}$ & \\
\hline & $\begin{array}{c}\text { Defence Meteorological } \\
\text { Satellite Program (DMPS) }\end{array}$ & 2010 & Raster & $817 \mathrm{~m}$ & \\
\hline \multirow[t]{3}{*}{ Terrain } & $\begin{array}{l}\text { Digital Elevation } \\
\text { Model(DEM) }\end{array}$ & 2013 & Raster & $30 \mathrm{~m}$ & https://lpdaac.usgs.gov/ \\
\hline & Slope & 2013 & Raster & $30 \mathrm{~m}$ & Calculated from DEM \\
\hline & Aspect & 2013 & Raster & $30 \mathrm{~m}$ & Calculated from DEM \\
\hline \multirow[t]{2}{*}{ Soil } & Percentage of sand & 2009 & Raster & $817 \mathrm{~m}$ & http://westdc.westgis.ac.cn/ \\
\hline & Percentage of silt & 2009 & Raster & $817 \mathrm{~m}$ & \\
\hline
\end{tabular}


Table A1. Cont.

\begin{tabular}{|c|c|c|c|c|c|}
\hline Category & Data & Year & Data Type & Resolution & Data Resource \\
\hline \multirow{3}{*}{ Climate } & Percentage of clay & 2009 & Raster & $817 \mathrm{~m}$ & \multirow{3}{*}{ http://www.resdc.cn/ } \\
\hline & Annual mean temperature & 2010 & Raster & $1 \mathrm{~km}$ & \\
\hline & $\begin{array}{c}\text { Annual mean } \\
\text { precipitation } \\
\text { Normalized Difference }\end{array}$ & 2010 & Raster & $1 \mathrm{~km}$ & \\
\hline NDVI & $\begin{array}{l}\text { Vegetation Index } \\
\text { (NDVI) data }\end{array}$ & 2017 & Raster & $1 \mathrm{~km}$ & http://www.resdc.cn/ \\
\hline Location & Road network & 2020 & Vector & - & https: \\
\hline \multirow{4}{*}{$\begin{array}{l}\text { Basic map of } \\
\text { Beijing }\end{array}$} & Road network & 2010 & Vector & - & $\begin{array}{l}\text { edu/data/set/groads-global- } \\
\text { roads-open-access-v1\# }\end{array}$ \\
\hline & $\begin{array}{l}\text { Ecological protection red } \\
\text { line map }\end{array}$ & 2017 & Other data & $1: 5000$ & $\begin{array}{c}\text { http://www.beijing.gov.cn/ } \\
\text { zhengce/zhengcefagui/201905 } \\
\text { /t20190522_61382.html }\end{array}$ \\
\hline & $\begin{array}{l}\text { Basic farmland } \\
\text { conservation } \\
\text { planning map }\end{array}$ & 2017 & Other data & $1: 5000$ & $\begin{array}{l}\text { http://www.beijing.gov.cn/ } \\
\text { gongkai/guihua/wngh/cqgh/ } \\
\text { 201907/t20190701_100008.html }\end{array}$ \\
\hline & $\begin{array}{l}\text { Historical and cultural } \\
\text { protection planning map }\end{array}$ & 2017 & Other data & $1: 5000$ & \\
\hline
\end{tabular}
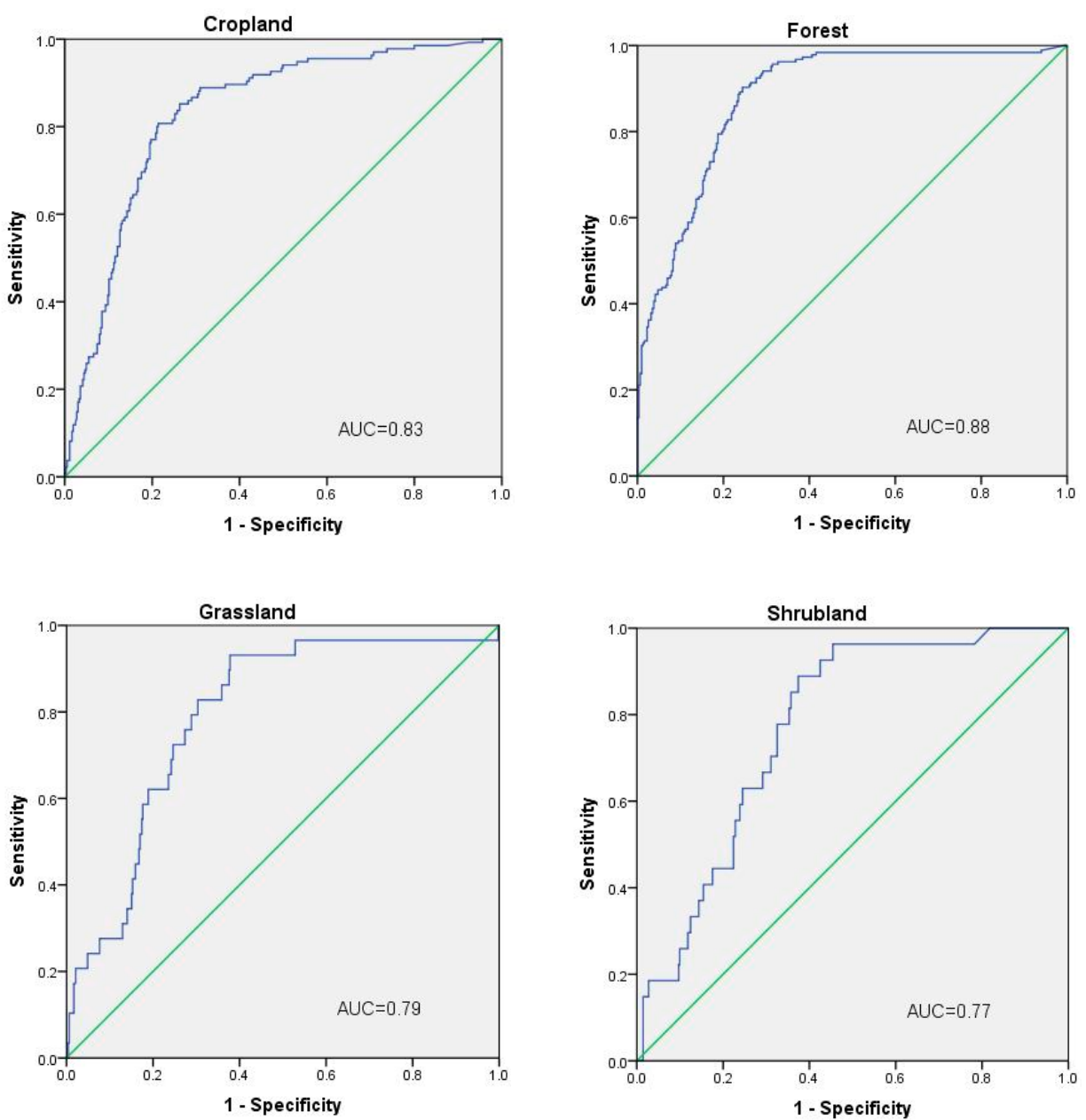

Figure A1. Cont. 

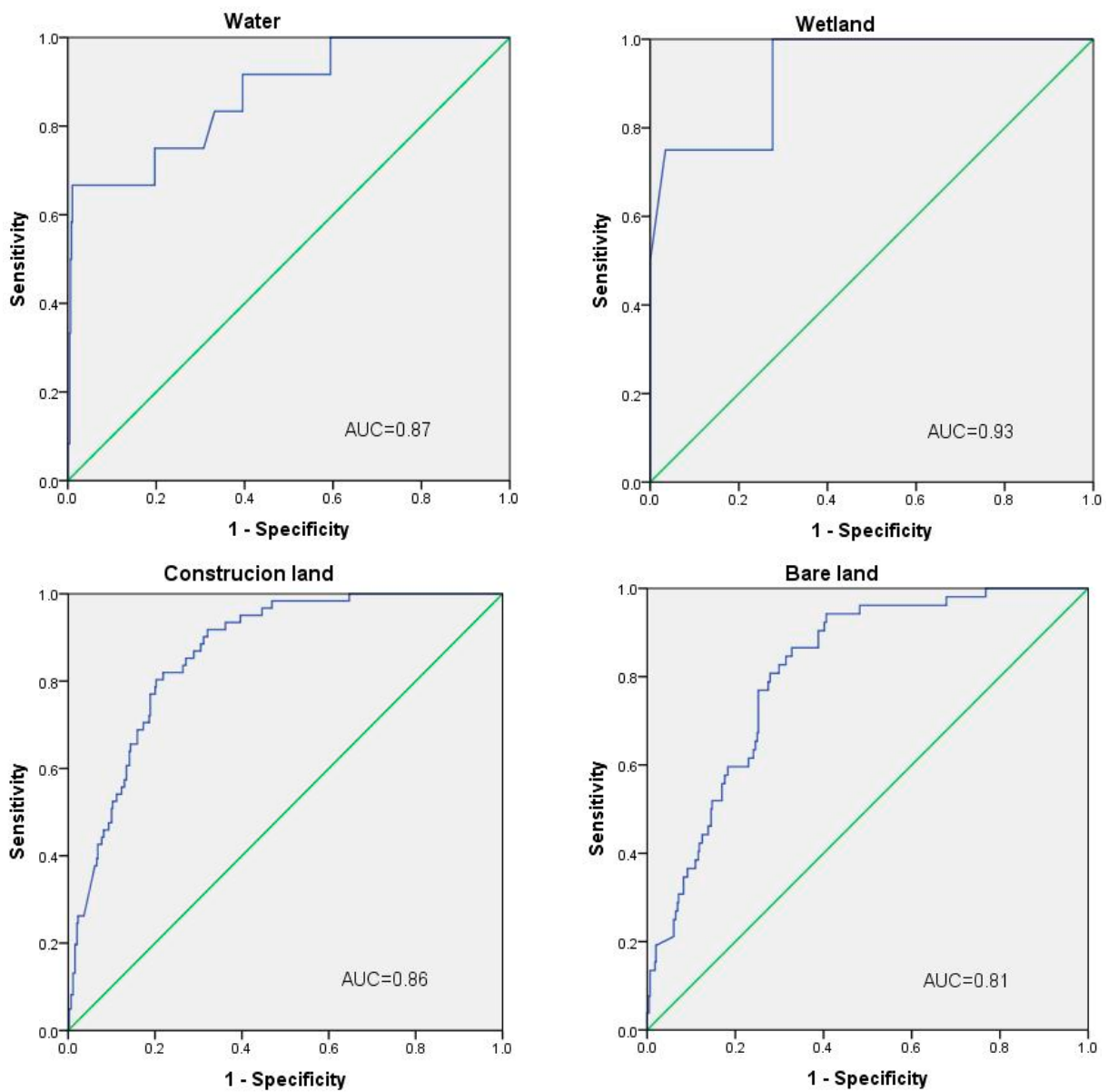

Figure A1. AUC values and ROC curves of each landscape type fitted by the artificial neural network (ANN).

\section{References}

1. Bourne, L.S. Internal structure of the city: Readings on urban form, growth, and policy. Historian 1982, 26, 1-18. [CrossRef]

2. Liu, M.; Hu, Y.; Li, C. Landscape metrics for three-dimensional urban building pattern recognition. Appl. Geogr. 2017, 87, 66-72. [CrossRef]

3. Xu, X.; Ou, J.; Liu, P.; Liu, X.; Zhang, H. Investigating the impacts of three-dimensional spatial structures on CO2 emissions at the urban scale. Sci. Total Environ. 2020, 143096. [CrossRef] [PubMed]

4. Luo, X.; Lu, X.; Jin, G.; Wan, Q.; Zhou, M. Optimization of urban land-use structure in China's rapidly developing regions with eco-environmental constraints. Phys. Chem. Earth Parts A B C 2019, 110, 8-13. [CrossRef]

5. Song, X.; Feng, Q.; Xia, F.; Li, X.; Scheffran, J. Impacts of changing urban land-use structure on sustainable city growth in China: A population-density dynamics perspective. Habitat Int. 2021, 107, 102296. [CrossRef]

6. Al-Saadi, L.M.; Jaber, S.H.; Al-Jiboori, M.H. Variation of urban vegetation cover and its impact on minimum and maximum heat islands. Urban Clim. 2020, 34, 100707. [CrossRef]

7. Lin, J.; Huang, B.; Chen, M.; Huang, Z. Modeling urban vertical growth using cellular automata-Guangzhou as a case study. Appl. Geogr. 2014, 53, 172-186. [CrossRef]

8. Crooks, A.; Pfoser, D.; Jenkins, A.; Croitoru, A.; Stefanidis, A.; Smith, D.; Karagiorgou, S.; Efentakis, A.; Lamprianidis, G. Crowdsourcing urban form and function. Int. J. Geogr. Inf. Sci. 2015, 29, 1-22. [CrossRef]

9. Yang, Y.; Bao, W.; Liu, Y. Coupling coordination analysis of rural production-living-ecological space in the Beijing-Tianjin-Hebei region. Ecol. Indic. 2020, 117, 106512. [CrossRef]

10. Zou, L.; Liu, Y.; Wang, J.; Yang, Y. An analysis of land use conflict potentials based on ecological-production-living function in the southeast coastal area of China. Ecol. Indic. 2021, 122, 107297. [CrossRef]

11. Zou, L.; Liu, Y.; Yang, J.; Yang, S.; Wang, Y.; Cao, Z.; Hu, X. Quantitative identification and spatial analysis of land use ecological-production-living functions in rural areas on China's. Habitat Int. 2020, 100, 102182. [CrossRef]

12. Bai, X.; Shi, P.; Liu, Y. Realizing China's Urban dream. Nature 2014, 509, 158-160. [CrossRef] [PubMed]

13. Gu, C.L.; Guan, W.; Liu, H. Chinese urbanization 2050: SD modeling and process simulation. Sci. China Earth Sci. 2017, 60, 1067-1082. [CrossRef]

14. Karen, C.S. Global forecasts of urban expansion to 2030 and direct impacts on biodiversity and carbon pools. Proc. Natl. Acad. Sci. USA 2012, 109, 16083-16088. 
15. Qiu, B.; Li, H.; Tang, Z.; Chen, C.; Berry, J. How cropland losses shaped by unbalanced urbanization process? Land Use Policy 2020, 96, 104715. [CrossRef]

16. Vimal, R.; Geniaux, G.; Pluvinet, P.; Napoleone, C.; Lepart, J. Detecting threatened biodiversity by urbanization at regional and local scales using an urban sprawl simulation approach: Application on the French Mediterranean region. Landsc. Urban Plan. 2012, 104, 343-355. [CrossRef]

17. Zhang, Y.; Liu, Y.; Zhang, Y.; Liu, Y.; Zhang, G.; Chen, Y. On the spatial relationship between ecosystem services and urbanization: A case study in Wuhan, China. Sci. Total Environ. 2018, 637-638, 780-790. [CrossRef]

18. Portela, R.; Rademacher, I. A dynamic model of patterns of deforestation and their effect on the ability of the Brazilian Amazonia to provide ecosystem services. Ecol. Model. 2001, 143, 115-146. [CrossRef]

19. Pontius, R.; Cornell, J.; Hall, C. Modeling the spatial pattern of land-use change with GEOMOD2: Application and validation for Costa Rica. Agric. Ecosyst. Environ. 2001, 85, 191-203. [CrossRef]

20. Barredo, J.; Kasanko, M.; McCormick, N.; Lavalle, C. Modelling dynamic spatial processes: Simulation of urban future scenarios through cellular automata. Landsc. Urban Plan. 2003, 64, 145-160. [CrossRef]

21. Clarke, K.; Hoppen, S.; Gaydos, L. A self-modifying cellular automaton model of historical urbanization in the San Francisco Bay area. Environ. Plan. B Plan. Des. 1997, 24, 247-261. [CrossRef]

22. Huang, D.; Huang, J.; Liu, T. Delimiting urban growth boundaries using the CLUE-S model with village administrative boundaries. Land Use Policy 2019, 82, 422-435. [CrossRef]

23. Liu, G.; Jin, Q.; Li, J.; Li, L.; He, C.; Huang, Y.; Yao, Y. Policy factors impact analysis based on remote sensing data and the CLUE-S model in the Lijiang River Basin, China. Catena 2017, 158. [CrossRef]

24. Verburg, P.H.; Koning, G.; Kok, K.; Veldkamp, A.; Bouma, J. A spatial explicit allocation procedure for modelling the pattern of land use change based upon actual land use. Ecol. Model. 1999, 116. [CrossRef]

25. Verburg, P.H. Veldkamp, A. Projecting land use transitions at forest fringes in the Philippines at two spatial scales. Landsc. Ecol. 2004, 19. [CrossRef]

26. Chebeane, H.; Echalier, F. Towards the use of a multi-agents event based design to improve reactivity of production systems. Comput. Ind. Eng. 1999, 37, 9-13. [CrossRef]

27. Huang, Q.; Song, W. A land-use spatial optimum allocation model coupling a multi-agent system with the shuffled frog leaping algorithm. Comput. Environ. Urban Syst. 2019, 77, 101360. [CrossRef]

28. Liu, X.P.; Liang, X.; Li, X.; Xu, X.; Wang, S. A future land use simulation model (FLUS) for simulating multiple land use scenarios by coupling human and natural effects. Landsc. Urban Plan. 2017, 168, 94-116. [CrossRef]

29. Fu, Q.; Hou, Y.; Wang, B.; Bi, X.; Zhang, X. Scenario analysis of ecosystem service changes and interactions in a mountain-oasisdesert system: A case study in Altay Prefecture, China. Sci. Rep. 2018, 8. [CrossRef]

30. Liang, X.; Liu, X.; Li, X.; Chen, Y.; Tian, H.; Yao, Y. Delineating multi-scenario urban growth boundaries with a CA-based FLUS model and morphological method. Landsc. Urban Plan. 2018, 177, 47-63. [CrossRef]

31. Lin, W.B.; Sun, Y.; Nijhuis, S.; Wang, Z. Scenario-based flood risk assessment for urbanizing deltas using future land-use simulation (FLUS): Guangzhou Metropolitan Area as a case study. Sci. Total Environ. 2020, 739, 139899. [CrossRef] [PubMed]

32. Li, F.; Ye, Y.; Song, B.; Wang, R. Evaluation of urban suitable ecological land based on the minimum cumulative resistance model: A case study from Changzhou, China. Ecol. Model. 2015, 318, 194-203. [CrossRef]

33. Li, S.; Xiao, W.; Zhao, Y.; Lv, X. Incorporating ecological risk index in the multi-process MCRE model to optimize the ecological security pattern in a semi-arid area with intensive coal mining: A case study in northern China. J. Clean. Prod. 2020, 247, 119143. [CrossRef]

34. Zhang, Y.J.; Yu, B.Y. Analysis of urban ecological network space and optimization of ecological network pattern. Acta Ecol. Sin. 2016, 36, 6969-6984.

35. Wu, J.S.; Zhang, L.Q.; Peng, J.; Feng, Z.; Liu, H.M.; He, S.B. The integrated recognition of the source area of the urban ecological security pattern in Shenzhen. Acta Ecol. Sin. 2013, 33, 4125-4133.

36. Zhang, J.; Qiao, Q.; Liu, C.; Wang, H.; Pei, X. Ecological land use planning for Beijing City based on the minimum cumulative resistance model. Acta Ecol. Sin. 2017, 37, 28-36.

37. Costanza, R.; dA'rge, R.; de Groot, R.; Farberk, S.; Belt, M. The value of the world's ecosystem services and natural capital. Ecol. Econ. 1997, 25, 3-15. [CrossRef]

38. Knaapen, J.; Scheffer, M.; Harms, B. Estimating habitat isolation in landscape planning. Landsc. Urban Plan. 1992, 23, 1-16. [CrossRef]

39. Yu, K.J. Landscape ecological security patterns in biological conservation. Acta Ecol. Sin. 1999, 19, 8-15.

40. Lu, Q.; Chang, N.; Joyce, J.; Chen, A.; Savic, D.; Djordjevic, S.; Fu, G. Exploring the potential climate change impact on urban growth in London by a cellular automata-based Markov chain model. Comput. Environ. Urban Syst. 2017, 68, 121-132. [CrossRef]

41. Pontius, R.; Boersma, W.; Castell, J.; Clarke, K.; Nijs, T.; Charles, D.; Zeng, Q.; Eric, F.; Noah, G.; Kasper, K.; et al. Comparing the input, output, and validation maps for several models of land change. Ann. Reg. Sci. 2008, 42, 11-37. [CrossRef]

42. Liang, X.; Liu, X.; Li, D.; Zhao, H.; Chen, G. Urban growth simulation by incorporating planning policies into a CA-based future land-use simulation model. International J. Geogr. Inf. Sci. 2018, 32, 2294-2316. [CrossRef]

43. Pontius, R.G.; Huffaker, D.; Denman, K. Useful techniques of validation for spatially explicit land-change models. Ecol. Model. 2004, 179, 445-461. [CrossRef] 
44. Pontius, R.G.; Millones, M. Death to Kappa: Birth of quantity disagreement and allocation disagreement for accuracy assessment. Int. J. Remote Sens. 2011, 32, 4407-4429. [CrossRef]

45. Hanley, J.A.; McNeil, B.J. The meaning and use of the area under a receiver operating characteristic (ROC) curve. Radiology 1982, 143, 29-36. [CrossRef] [PubMed]

46. Peng, Y.F. Metropolitan Land Use Optimization Simulation Based on FLUS Model—Setting Shenzhen City as an Example. Shandong Land Resour. 2019, 35, 70-74.

47. Yu, D.; Liu, Y.; Fu, B. Urban growth simulation guided by ecological constraints in Beijing city Methods and implications for spatial planning. J. Environ. Manag. 2019, 243, 402-410. [CrossRef] 